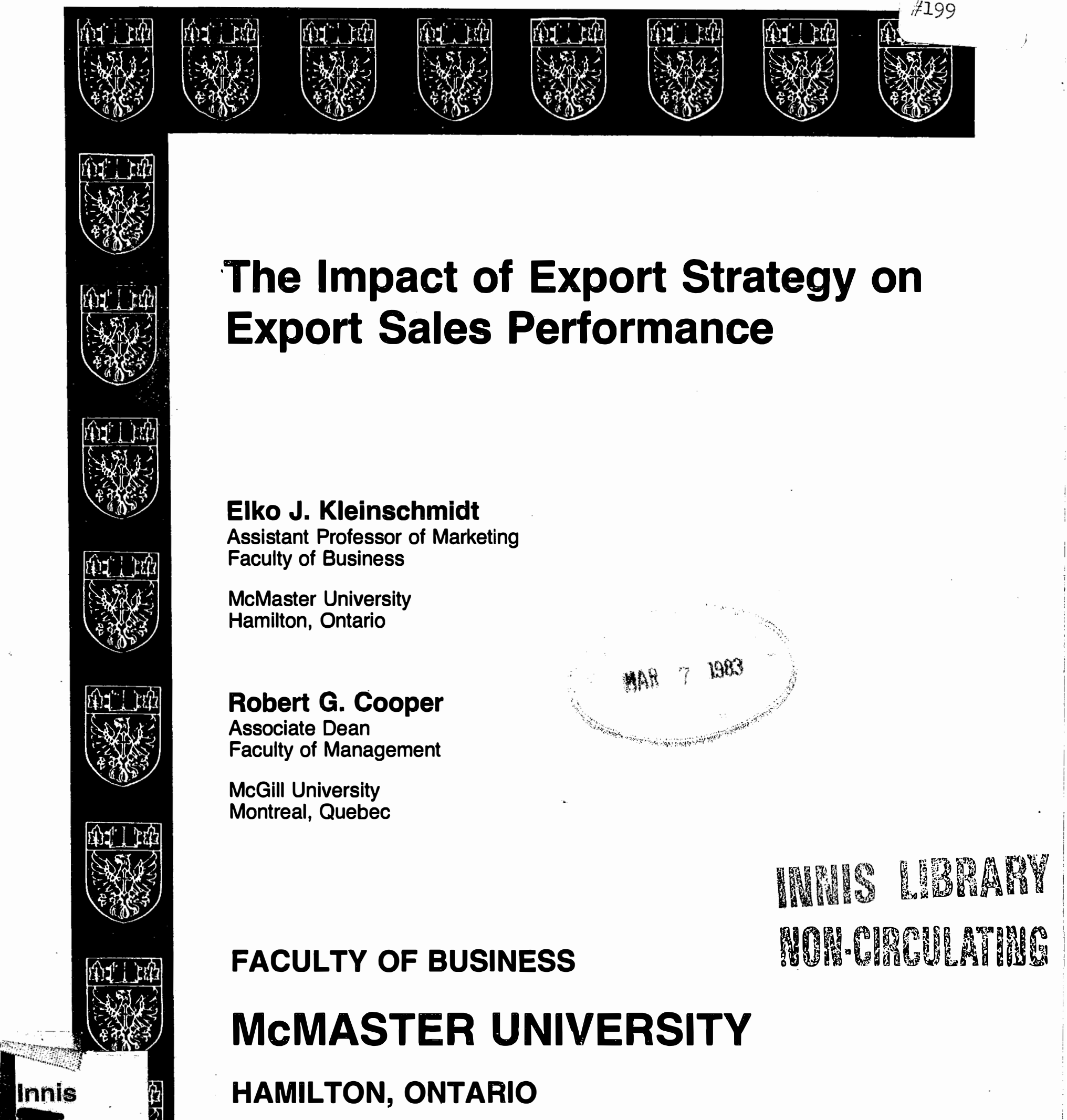

\author{
Research and Working Paper Series No. 199
} January, 1983 


\section{THE IMPACT OF EXPORT STRATEGY ON \\ EXPORT SALES PERFORMANCE}

\section{INTRODUCTION}

Export sales are increasingly seen as one route to corporate growth for the small-to-medium sized firm. But the question of which export strategy to elect -- product strategy, segmentation strategy, choice of export markets, etc. -- remains a concern for most exporters. This article reports the results of an extensive empirical investigation of heavy exporters in one industry, and how the specific export strategies that these firms elected impact on their export performance.

Many managements look to foreign markets because of increasing competition at home, maturing domestic markets, or limited domestic market opportunities. Exporting as a means to corporate growth is particularly appropriate for manufacturers of industrial goods, where international cultural differences are not likely to deter foreign sales (as is the case with many consumer goods) [20]; for smaller firms, where direct foreign investment is beyond their financial and managerial capabilities; and for firms with products possessing innovative advantages [22].

The field of export marketing strategy has been a neglected one, however, both in terms of text book material and empirical investigations at the firm level. First, much academic research on international trade has dealt with entire industries rather than individual firms, or has centred on the MNC (multinational corporation) all but ignored the exporter. Second, no study has dealt with the role of strategy as a determinant of export performance.

Those studies that do focus on export marketing have investigated a myriad

1

The data and findings are based on a Ph.D. dissertation by Kleinschmidt [14]. 
of firm, managerial and market characteristics that are associated wi th higher levels of exports. Factors that have been found to be tied to export performance (usually defined as export sales level) fall into four categories:

1. Management expectations and perceptions, including: perceptions of export risk $[1,7,18,19,21]$; export expectations of top management $[1,13,18]$; export cost expectations $[7,19]$; and management expectations of export profitability $[1,13,18,20]$.

2. Market variables, including: size of foreign markets [8]; level of competition in foreign markets [17]; domestic market share [17]; trade barriers $[1], 16]$; and physical and psychological distance to foreign markets $[1,12,17]$.

3. Differential advantages and resources of the firm, including: product advantages and product adaptation $[5,7,11]$; technological advantages $[5,7$, $10,17]$; and distribution advantages $[12,19]$.

4. Firm demographics, including: size of firm $[5,7,10,23]$; firm ownership $[7,10]$; and years of export experience $[8,16]$.

Indeed, of the 24 studies of export performance and behavior that we identified, not one directly posed the question: what export marketing strategies do firms adopt and which strategies yield the best results (although certain studies did deal with individual elements of strategy, namely product adaptation and countries exported to)?

Numerous investigations and writings on domestic marketing strategy point to the important part that strategy selection plays [4,20]. The role of marketing strategy cannot be understated, whether for domestic or for export operations. Clearly there is a need to examine the different types of strategies that firms adopt when marketing to foreign countries. An equally important issue concerns the relative merits of each strategy. Finally, an understanding of what types of firms typically opt for which strategies would provide an insight into the appropriateness of alternate strategies for different firms. These questions are 
addressed by the research reported in this article.

\section{A CONCEPTUAL FRAMENORK}

A conceptual framework was first developed in order to help structure the research and to identify variables for measurement. The undertying proposition of the research is that the export performance a firm achieves is largely determined by the export strategy a firm adopts.

The dimensions of an export strategy closely parallel those of a domestic marketing strategy. A marketing strategy is normally defined in terms of two key dimensions, namely market selection and product strategy $[2,6,15]$, and is represented pictorally in the form of a product/market matrix. For the specific case of export marketing, product strategy translates intó "product adaptation policy", or the degree to which a firm adapts its products for foreign markets: at one extreme is the firm that simply sell's its domestic product abroad with minimum adaptation; at the other extreme is the firm that develops products specifically for its export markets.

The morket selection facet of strategy in export marketing is captured by two dimensions, namely the countries exported to and the level of market segmentation within these countries [3]. In terms of countries., export market selection ranges from a "nearest neighbor" approach (exporting to a convenient and proximate country) to a world orientation, where a firm's exports are sold to different countries around the world. For example, Grohang notes that for Norwegian firms the nearest neighbor approach amounts to selling to other Scandinavian countries [9]; in North America, the familiar U.S.-Canada trade patterns typify the nearest neighbor strategy.

The second market selection dimension -- segmentation strategy -- portrays 
the degree of market segmentation that firms utilize within their export markets, i.e. does the firm sell to essentially one and the same market segment in its foreign markets $[22,23]$, or does it cater to a multitude of different segments? Export marketing strategy, in the current research, was therefore defined in terms of three dimensions:

- degree of product adaptation;

* countries exported to (neighbor versus world); and

- level of market segmentation.

Splitting firms into two categories on each dimension yields a 2 by 2 by 2 cube that represents the eight possible strategy combinations.

Export performance has traditionally been measured by a single variable, namely export sales. as a percent of total corporate sales, called "export level". But in other contexts, growth is considered to be an important and dynamic measure of performance. In this research, therefore, both export level and export growth were considered as gauges of export performance.

Many studies have shown that characteristics of the firm are tied to export performance. The focus of the current research was not on how these characteristics might be predictors of export performance, but rather on how strategy impacts on performance. Nonetheless, these company characteristics do provide a setting for the export strategy, and a relationship between strategy elected and firm characteristics can be expected. The firm characteristics considered in this research comprise five blocks of variables:

1. Firm demographics, including: size of firm; age of firm; export experience; and firm ownership (foreign versus domestic).

2. Managerial perceptions of market conditions, including: perceptions of the level of competition in the main markets; export barriers; perceptions of domestic market potential; and intentions re. direct foreign investment.

3. Differential advantages of the firm, including: product advantage; price advantage; distribution advantage; advertising/promotion advantage; export policy constraints (a negative advantage). 
4. Export support activities, including: export marketing planning efforts; export marketing research efforts; use of external information sources; level of foreign visits; and R\&D spending.

5. Goals and aspirations, including: expectations for exports; corporate growth goals; and corporate goals re. security of inves.tment.

The marketing concept dictates that firms shouTd practice market segmentation and design product offerings to suit their target market. The logical extension, in exporting marketing, is that firms which elect a product adaption and market segmentation strategy can be expected to perform better than those that do not. Moreover, economic theory suggests that the firm that selects its market with a view to the magnitude of opportunity and the nature of the firm's own competences should out-perform the firm that restricts itself to a nearby or convenient market. Additionally, certain world markets are growing more quickly than nearby markets. ${ }^{2}$ Therefore, a world oriented strategy can be expected to. out-perform a nearest neighbor approach. The following research statements evolve from these expectations:

1. Export performance is related to the type of export strategy elected, and, in particular, is positively tied to the following strategic directions:

-- product adaptation strategy (versus a non-adaptive approach);

-- a segmentation strategy (versus no segmentation); and

-- world orientation (versus a nearest neighbor approach).

2. Different types of firms select different export strategies. While the research statements may seem self evident, the magnitude of the differences in performance and the types of firms that select each strategy are of particular interest to both the export strategist and the marketing academic.

RESEARCH METHOD

Managers in total of 142 firms in the Canadian electronics industry were

2

Note: Canadian firms provided the data; thus the "nearest neighbor" market was the U.S., which has experienced slower growth than certain other countries. 
personally interviewed to obtain data on export strategies and performance. A single industry was chosen in order to control for industry differences. The electronics industry provided an ideal setting for the study: many small-to-medium. sized firms, which were heavily engaged in the export of moderate-to-high technology products.

Initialty, 269 firms were contacted by mail and asked to participate in the study. A total of 192 firms replied $(70.6 \%)$, which, folTowing screening for appropriateness, was reduced to 142 firms. Those 142 firms finally interviewed represented $43 \%$ of the total number of Canadian electronics firms and an estimated $60 \%$ of output (industrial goods only).

The average firm in the eventual sample had annual sales of $\$ 18.5$ million, and exported $46 \%$ of its output. Of these exports, on average $53 \%$ was destined to the nearest neighbor (the U.S.) and $47 \%$ to other countries. The median number of employees per firm was approximately 100; the median age of the firm about 15 years; and almost $60 \%$ of the firms had 10 years or less export experience. One third of the firms were foreign-owned.

Within each firm, managers were asked about their export marketing strategies, namely the countries exported to (and split of exports by country), the nature and number of segments catered to, and product adaptation practices. A nearest neighbor exporter (versus world exporter) was defined as a firm which exported more than $67 \%$ of its exports to one country ${ }^{3}$ (in this case, the U.S.). Firms that sold to two or more market segments within their foreign markets were classed as multi-segmenters (versus single segment). Product adapters were defined as firms

3

Note: that on average $67 \%$ of Canadian manufactured exports are destined to U.S. markets (excludes Autopact). 
which adapted their products beyond the minimat requirements. for export markets. 4

The sample of firms was then categorized into the eight possible export strategies. Two of the cells had a decidely lower firm frequency than the other cells, and therefore were combined with two other cells. The resulting six strategy groups are defined in terms of wortd versus nearest neighbor approach and a "marketing". versus "seTTing" orientation. Here a "marketer" practices both product adaptation and market segmentation concurrently; in contrast a "seller" neither adapts his products nor practices market segmentation; and a third category falling between the two extremes, the quasi-marketer, practices either product adaptation or segmentation, but not both concurrently. The definition and frequency of these strategy types is shown in Table I. Note that only a small proportion of firms -- less than one in seven -- elected the normative strategy of a world oriented marketer; that only $29 \%$ practiced a marketing approach; but that almost $60 \%$ had a world orientation.

\section{RESULTS}

Impact of Strategy

The export strategy elected -- whether marketing versus selling, and world versus nearest neighbor -- has a dramatic impact on export results. Table II shows this impact. Note that firms electing a wortd moxketer strategy achieved an exceptional annual growth ${ }^{5}$ in exports of $188 \%$ versus a low of only $23 \%$ for nearest neighbor sellers -- an eight-fold difference in performance. Similarly, world marketers saw $52.5 \%$ of their output as exports, almost double the $29.3 \%$ level

4

In order to classify firms as product adaptors (or non-adaptors) and segmenters (or non-segmenters), Likert type multi-item scales were used: five items for the product adaptation dimension and four items for the market segmentation dimension:

5

Compounded export sales growth for the last three years. 
DEFINITION OF STRATEGY TYPES

World

Nearest Neighbor

Marketer

Quasi-

Marketer

Seller

$\%$ of exports destined to nearest neighbor (mean)
Adapts products and segments markets and markets to the world.

$13.5 \%$ of firms

Either adapts products. or segments markets, but not both; exports to the world.

$28.4 \%$ of firms

No product adaptation and no market segmentation, and sells to the world.

$17.7 \%$ of firms

$28.1 \%$
Adapts products and segments markets, and markets mainly to nearest neighbor.

$15.6 \%$ of firms

Either adapts products or segments markets but not both; exports mainly to nearest neighbor.

12.8\% of firms

No product adaptation and no market seamentation; and sells mainly to nearest neighbor.

$12.0 \%$ of firms

\begin{tabular}{|c|c|}
\hline $17.7 \%$ of firms. & $12.0 \%$ of firms \\
\hline $28.1 \%$ & $90.2 \%$ \\
\hline
\end{tabular}


TABLE II

EXPORT PERFORMANCE VERSUS

EXPORT STRATEGY

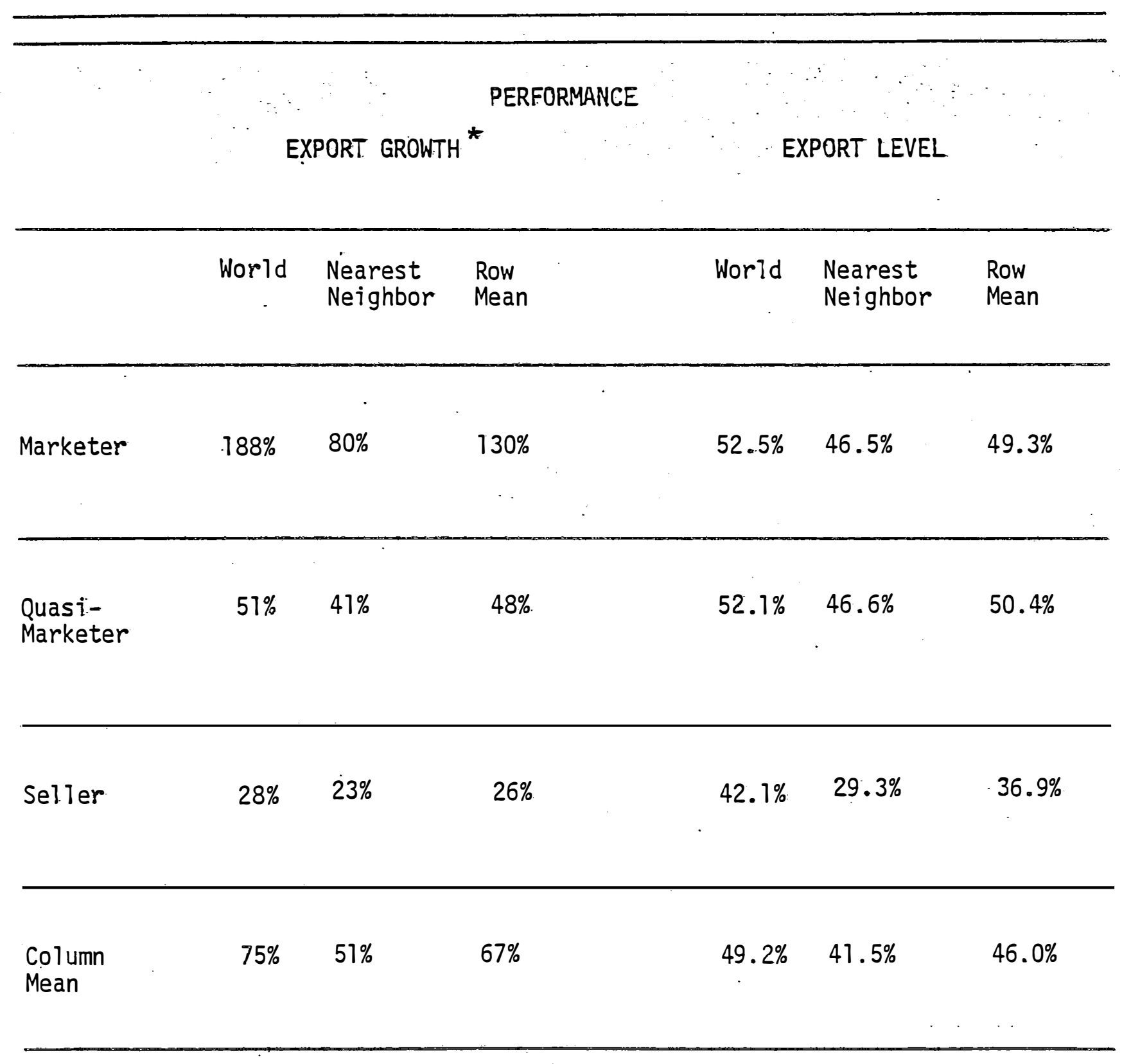

* Annual growth rate, compounded over Tast three years. 
realized by nearest neighbor sellers.

- Export Growth:

Export growth, the dynamic measure of performance, was closely related to bath dimensions of export strategy, with the marketer/seller dimension having a stronger effect than world/neighbor direction. Overall, marketing firms, practicing both product adaptation and segmentation, saw their exports grow at 130\% annually versus only $26 \%$ for sellers. Similarly world exporters witnessed a growth of $75 \%$ versus $51 \%$ for nearest neighbor exporters.

Not surprisingly, this impact of strategy on export growth was strongly significant. Two way analysis of variance of export growth versus the two strategy dimensions (marketer/seller and world/neighbor) was statistically significant at the 0.00T level. Table III presents the ANOVA results. Note that the main effects were highly significant $(\alpha \leq 0.001)$, with the degree of marketing orientation significant at the 0.001 level, and degree of world orientation at the 0.08 lever. But the interaction effects of these two dimensions was not significant $(\alpha \leq 0.10)$.

\section{- Export Level :}

Export level, the static performance measure, was also significantly related to the export strategy elected, but not as strongly so as export growth. At one extreme, firms electing a world marketing strategy -- product adaptation, market segmentation and a world focus -- exported more than half their domestic production (52.5\%). In contrast, those firms classed as nearest neighbor sellers, who sold unadapted products to the same segment in a nearby market of convenience, fared much worse with only $29.3 \%$ of their sales in exports.

The export levels versus strategies elected, shown in Table II, reveal a consistent pattern, with performance increasing with both a marketing and a world 
TABLE II I

ANOVA RESULTS: THE IMPACT

OF EXPORT STRATEGY ON EXPORT GROWTH

\begin{tabular}{|c|c|c|c|}
\hline Source of Variation & $\begin{array}{l}\text { Degrees: of } \\
\text { Freedom }\end{array}$ & $F$ & $\begin{array}{l}\text { Signifiance } \\
\text { af } F \\
\quad \therefore\end{array}$ \\
\hline $\begin{array}{l}\text { Main Effects } \\
\text { - Marketer vs Seller } \\
\text { - World vs Neighbor }\end{array}$ & $\begin{array}{l}3 \\
2 \\
1\end{array}$ & $\begin{array}{l}6.7 T \\
8.54 \\
3.07\end{array}$ & $\begin{array}{l}0.001 \\
0.000 \\
0.082\end{array}$ \\
\hline Interaction Effects & 2 & 2.06 & 0.131 \\
\hline Explained & 5 & 4.49 & 0.001 \\
\hline
\end{tabular}


orientation. On average, marketing oriented firms out-performed sellers (49.3\% export sales versus $36.9 \%)$, and world oriented firms outdid nearest neighbor exporters ( $49.2 \%$ versus $41.5 \%$ ), but less dramatically.

The performance differences, guaged by export level, were statistically significantly related ta strategy $(\alpha=0.06)$. Two way analysis of variance (Table IV). showed export level to be strongty tied to the marketer/seller dimension $(\alpha=0.027)$. Although tendencies between export level and the world/neighbor dimension were evident, this relationship was not significant at the 0.10 level. But overail, the main effects of the strategy elected were significant $(\alpha \leq 0.10)$.

\section{- Performance on Both Dimensions:}

Which strategies result in both high export growth and high export level simultaneously? Note that the two performance criteria -- growth and level -were virtually independent guages of export results $(r=0.091)$.

The "high performance" firms were identified in order to answer this question. Firms were split into two categories on each performance criterion (high and low, or firms above and below the median performance); yielding four categories of performance. Of particular interest were those firms in the HH cell: the "high performance" firms that simultaneously achieved both high export growth and high export level. Table $V$ shows the proportion of HH firms for each strategy elected.

The world marketers clearly out-performed the other strategy groups with almost half $(47 \%)$ of world marketers classed as $\mathrm{HH}$ or high performance firms. Only $5.3 \%$ of world marketers were poor performers on both criteria, the LL firms. These trends shown in Table $V$ were statistically significant (chi squared; $\alpha=0.04$ ). In contrast, those firms electing a nearest neighbor selling strategy fared by far the worst: $29 \%$ of the firms that adopted this strategy were poor performers (LL firms), and only $5.9 \%$ high performance firms. The remainder were HL or LH firms. Regardless of whether a marketer or a seller, world oriented firms consistently 
TABLE IV

ANOVA RESULTS: THE IMPACT OF

EXPORT STRATEGY ON EXPORT LEVEL.

\begin{tabular}{|c|c|c|c|}
\hline Source of Variation & $\begin{array}{l}\text { Degrees of } \\
\text { Ereedom }\end{array}$ & $\mathrm{F}$ & $\begin{array}{l}\text { Significance } \\
\text { of } F\end{array}$ \\
\hline $\begin{array}{l}\text { Main Effects } \\
\text { - Marketer vs Seller } \\
\text { - World vs Neighbor }\end{array}$ & $\begin{array}{l}2 \\
1 \\
1\end{array}$ & $\begin{array}{l}3.56 \\
5.02 \\
2.09\end{array}$ & $\begin{array}{l}0.031 \\
0.027 \\
0.151\end{array}$ \\
\hline Interaction Effects & 1 & 0.37 & 0.545 \\
\hline Explained & 3 & 2.49 & 0.063 \\
\hline
\end{tabular}

Note: Because of clear performance similarities (See Table II), marketers and quasi-marketers were grouped together in this analysis. 
TABLE V

PROPORTION OF HIGH PERFORMERS

(AND LOW PERFORMERS) FOR EACH EXPORT STRATEGY

Wortd

Nearest

Neighbor

Row Means.

\begin{tabular}{|c|c|c|c|}
\hline Marketers & $\begin{array}{l}47.4 \% \\
(5.3 \%) *\end{array}$ & $\begin{array}{l}18.2 \% \\
(9.1 \%)\end{array}$ & $\begin{array}{l}31.7 \% \\
(7.3 \%)\end{array}$ \\
\hline $\begin{array}{l}\text { Quasi- } \\
\text { Marketers }\end{array}$ & $\begin{array}{c}22.5 \% \\
(22.5 \%)\end{array}$ & $\begin{array}{c}11.1 \% \\
(27.8 \%)\end{array}$ & $\begin{array}{c}19.0 \% \\
(24.1 \%)\end{array}$ \\
\hline
\end{tabular}

Sellers

$20.0 \%$

$(32.0 \%)$

$5.9 \%$

(29.4\%)

$74.3 \%$

(31.0\%)

Column

$27.4 \%$

Means

(21. $4 \%$ )

$12.3 \%$

$21.3 \%$

(21. $1 \%$ )

(21.3\%)

$\star$

Hote: Low performers, the LL firms, are shown in parenthesis.

The remaining firms, i.e., the other $47.3 \%$ in this strategy, are $L H$ or $H L$ firms 
outdid their nearest neighbor counterparts (Table V). Similarly, whether a world or neighbor strategy, the marketers always had a higher proportion of "high performance" firms. These tendencies were confirmed statistically: A MANOVA analysis, which tested for significant differences between strategy groups when considering both performance guages simuitaneously, was significant at the 0.007 Tevel.

The research findings strongty support the first research statement: a strategy that emphasizes a world orientation, product adaptation, and market segmentation yiefds better export performance. Export growth was considerably greater for such firms; export level was higher; and this strategy yielded a greater proportion of high performance firms in terms of both performance criteria.

\section{Strategy Profiles}

Certain types of firms were associated with each of the export strategies. In order to identify the profiles of firms that elected the six export strategies, one way analysis of variance with Duncan multiple range tests was employed.

Only four of the measures of firm characteristics were significantly tied to strategies (ANOVAS; $\alpha \leq 0.10$ ), although the range tests identified a total of ten of the 21 firm characteristics which differed between strategy groups $(\alpha \leq 0.10)$. The firm profiles are shown for each strategy type in Table VI for the ten significant firm characteristics only, and the profiles of four strategy groups are described below:

1. World Marketers:

World marketers, the best performers, were unique in that they were the youngest firms and also the least experienced firms in terms of exporting. Coincidently, they were the heaviest spenders on R\&D as a percentage of corporate sales, and undertook the most extensive export marketing planning activities. These world marketers also had the highest expectations for their export program. Of all firms, world marketers saw the fewest barriers to export marketing in foreign countries. Generally, perceived differential advantages -- product, distribution, promo- 


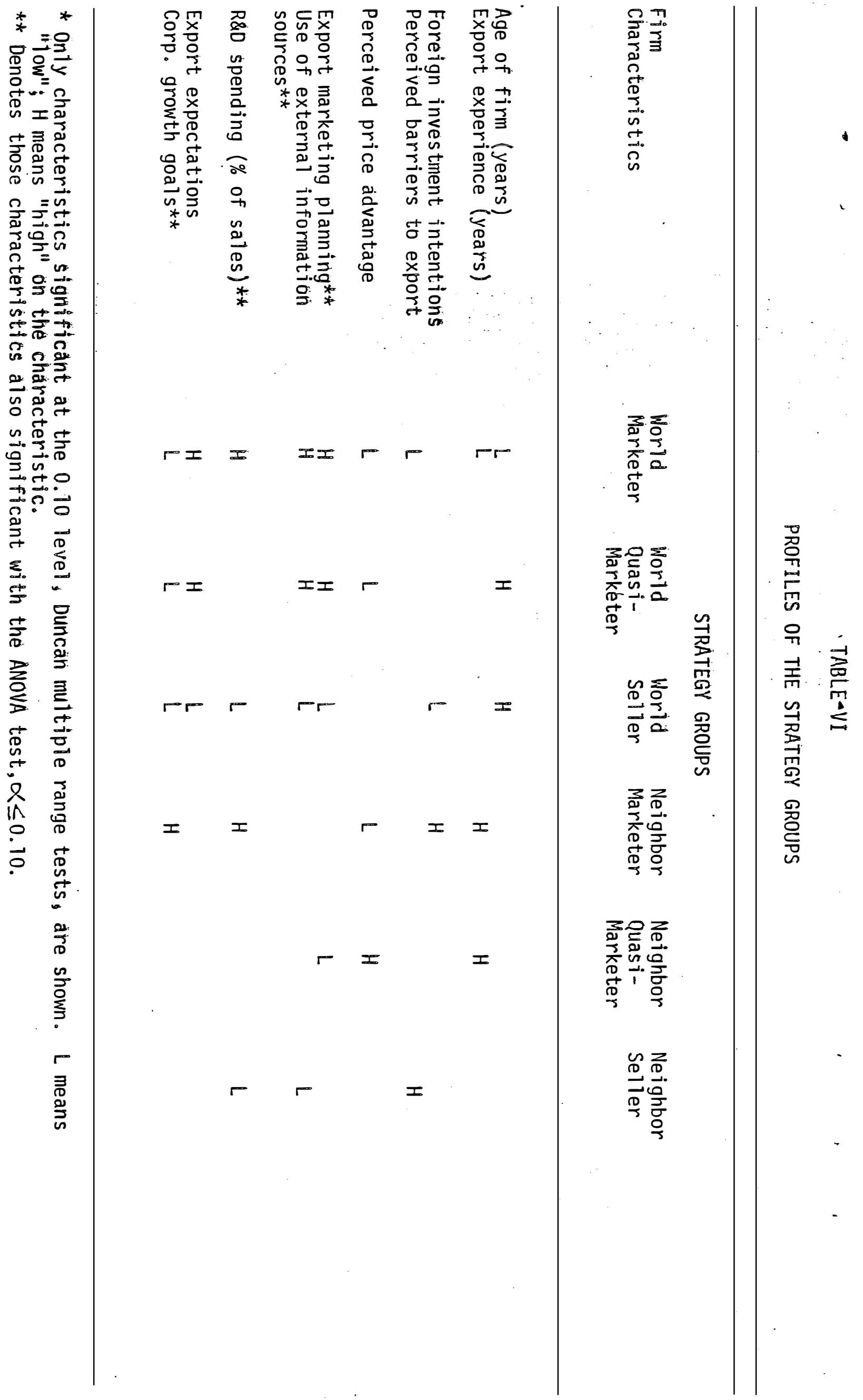


tion, etc. -- were not unique to any strategy group. The exception was price advantage, and, ironically, world marketers believed that they had the least price advantage of all firms. Finally, these firms, like the other marketing oriented firms, had low corporate growth goals relative to previous years' growth, probably a sober reflection of the difficulty in repeating the spectacular growth of pervious years.

What we witness is a consistent pattern of characteristics associated with these world marketers, the high performance firms. The picture is one of an aggressive and entrepreneurial firm: young and inexperienced; heavy R\&D spending but no product price advantage, suggesting a focus on product and technology rather than low prices; extensive export planning; and high export expectations. Export performance was exceptional: 188\% growth in exports, and 52.5\% of output as exports.

\section{World Sellers:}

The picture for world sellers is in direct contrast to that for world marketers. World sellers were the oldest firms in the sample. They made little use of export marketing planning, had the lowest R\&D spending of all firms, and had the lowest export expectations. Such firms made little use of outside information sources about their foreign markets. Like world marketers, world sellers had low corporate growth goals relative to previous years' growth rates. The pattern is one of a much more conservative, established firm: older, little R\&D, little export planning, and low expectations. Note that these firms achieved an export growth rate well below the average: $28 \%$ growth versus an all-finm average of $67 \%$. Moreover, the export level of these world sellers was also marginally lower than the average firm.

\section{Nearest Neighbor Marketers:}

Nearest neighbor marketers possessed fewer distinguishing characteristics. Such firms had the most export experience, and also had the strongest intentions 
of all firms to become involved in direct foreign investment. Like world marketers, they too perceived that they had no price advantage for their products and their $R \& D$ efforts were the highest of all firms. The growth in exports of nearest neighbor marketers was above average ( $80 \%$ versus $67 \%$ for all firms), while export level was just about average at $46.5 \%$.

\section{Nearest Neighbor SelTers:}

This small group of firms, representing only $12 \%$ of the sample, had very few unique characteristics. They made very little use of outside information sources in their foreign markets, the least of any firm. Further, they saw the highest barriers. to exports of all firms. Finally, they spent the least on R\&D but they were not significantly different in terms of age, export experience, export marketing planning, growth goals or export expectations. These firms were by far the worst performers, with an export growth rate of $23 \%$, well below the average of $67 \%$, and an export levei of $29.3 \%$, again far below the average of $46 \%$.

The different firm profiles that were identified across strategy groups and the results in Table VI lend only partial support to the second research statement: different firms elect different export strategies. Indeed, there were a number of significant differences particularly for the high performance firms, namely the world marketers.

But there were also many characteristics that did not vary across strategy groups. The size of the firm (annual sales) and firm ownership (domestic versus foreign owned) appear to have little to do with strategy elected. Perceptions regarding market potentials, both at home and abroad, were not tied to export strategies, nor were perceived differential advantages in terms of distribution, promotion and product. Finally, several support activities, namely foreign market research efforts and the level of foreign visits, were not particular to any one 
strategy type. The conclusion is, while some company differences did exist across strategy types, that these differences were not as great nor as numerous as might have been expected.

CONCLUSIONS

The research results show clearly that the export strategy a firm elects has a pronounced impact on the export performance results it achieves. In terms of relative impacts, the effects were:

- a marketing versus a selling orientation leads to much stronger export growth: $130 \%$ versus $26 \%$ growth.

- a marketing versus a selling orientation results in a considerably higher export level: $49.3 \%$ versus $36.9 \%$ of output.

- a world versus nearest neighbor orientation is tied to a somewhat stronger export growth: $75 \%$ versus $51 \%$ growth.

- a world versus nearest neighbor orientation has a small but positive impact on export leve1: $49.2 \%$ versus $41.5 \%$ of output.

A11 but the last relationship were statistically significant, but interactive effects between the two strategic directions were not significant.

The evidence strongly supports the tenets of the marketing concept as applied to international marketing: that market segmentation and designing products specifically to suit target market segments is an appropriate strategy. The marketing concept has found considerable favor in domestic operations, but has rarely been tested in an export context. The results of the current research help to extend the applicability of the marketing concept to export marketing.

The message for managers is. that product adaptation and market segmentation are key ingredients in success, not only at home, but also abroad. The manufacturer that is content merely to sell his domestic product abroad, essentially unaltered, and to pay little heed to the nature and selection of segments within his foreign markets, is likely to achieve a below average export performance, particularly in terms of export growth. But if a high export growth and, to a lesser extent, a high 
ievel of exports are desired, then a careful selection of target market segments with the product as a variable, and not fixed, is essential.

A second message is that a world versus a nearest neighbor orientation is probably the more preferred route, again if higher export growth is the objective. Many firms in our sample were content merely to select a foreign market that was convenient - a nearby market, both geographically and psychologically. But such a strategy of convenience may result in missed opportunities - markets that, while less convenient to access, promise higher payoffs. The performance results were clear: a world orientation leads to a considerably higher export growth, and a. somewhat higher export level.

Firms that elected the preferred strategy -- a world marketing strategy - were distinct from other firms in a number of important ways. Some of these characteristics, such as age and export experience, are attributes of the firm itself, and are not amenable to management action. But certain activities, which are within the control of management, were clearly associated with these high performers. High R\&D spending, and the reliance on technological prowess, rather than price advantages, were important features of these firms. Similarly, the use of extensive export marketing planning activities separated these world marketers from other firms. While no casuality was shown by the research, the evidence strongly suggests that both R\&D spending and export marketing planning are vital to highly successful export marketing.

Export success can never be guaranteed. There are simply too many unknowns and uncertainties to yield a reliable and valid prediction of success. But this research has demonstrated that certain strategies are more likely to lead to success than others. What is most surprising is the magnitude of the performance differences between strategies. Export strategy selection and implementation becomes a critical ingredient of export success. And a strategy that is based on the marketing concept and features a world orientation should become the ideal for firms that are intent on improving export performance. 


\section{REFERENCES}

[1] Abdel-Malek, Talaat, Managerial Export-Orientation: A Canadian Study, School of Business Administration, University of Western Ontario, 1974.

[2] Ames, B. Charles, "Marketing Planning for Industrial Products", Harvard Business Review, Sept.-0ct. 1968, pp. 100-117.

[3] Ayat, Igal and Jehiel Zif, "Marketing Expansion Strategies in Multinational Marketing", Journal of Marketing, Vo1. 43 (Spring 1979), pp. 84-94.

[4] Buzze11, Robert D., "Can you Standarize Multinational Marketing", Harvard Business Review, Nov.-Dec. 1968, pp. 108-117.

[5] Cavusgil, Salih Tamer, "Organizational Determinants of Firms' Export Behaviour: An Empirical Analysis", unpublished Ph.D. dissertation, University of Wisconsin-Madison, 1976.

[6] Corey, E.R., Industrial Marketing, Prentice-Hall, Inc., Englewood Cliffs, New Jersey, 1962.

[7] Daniels, John D: and Juan Goyburo, "The Exporter-Non-exporter Interface: A Search for Variables", Foreign Trade Review, No. 2, July-Sept. 197677 , pp. 258-282.

[8] Fenwick, Ian and Lyn Amine, "Export Performance and Export Policy:

Evidence from the U.K. Clothing Industry", Journal of the Operational Research Society, Vol. 30, No. 8, Great Britain, 1979, pp. 747-754.

[9] Grohang, Kjell, "Exploring Industrial Export Strategies," in An Assessment. of Marketing Thought and Practice, American Marketing Association Proceedings, \#48, 1982.

[30]. Hirsch, Seev, "Technological Factors in the Composition and Direction of Israel's Industrial Exports", in Raymond Vernon (ed), The Technology Factor in International Trade, Columbia University Press, New York, 1970, pp. 365-408.

[1] Kacker, Madhav P., "Export-Oriented Product Adaptation - Its Patterns and Problems", Management International Review, 1975/6, pp. 61-70.

[12] Khan, M. Sikander, "A Study of Success and Failure in Exports", Proceedings of the Annual Meeting of the European International Business Association, Dec. 14-16, 1978, pp. 1-7.

[13] Kizilbash, A.H. and C.A. Maile, "Export Marketing in a Changing Economic Environment", Journal of Smail Business Management, Vol. 15, 1977, No. 1, pp. $1-6$. 
[14] Kleinschmidt, Elko J., "Export Strategies, Firm Internal Factors and Export Performance of Industrial Firms: A Canadian Empirical Analysis," unpublished Ph.D. dissertation, McGill University, 1982.

[15] Luck, David J. and Arthur E. Pre11, Market Strategy, Prentice-Ha11, Inc., Englewood CTiffs, New Jersey, 1968.

[16] McDougal1, Gordon H.G. and Bruce W. Stening, "Something to Think About: Identifying the High Performance Exporters", Canada Commerce, Dec. 1975, pp. 12-15.

[17] McGuinness, Norman W., "The Impact of Technology and Product Characteristics on the International Sales of New Canadian Industrial Products: A Diffusion Analysis" unpublished Ph.D. dissertation, University of Western Ontario, Canada, February, 1978.

[18] Neide11, Lester A., "Comparative Export Practices of Small Firms in The U.S. and Scandinavia", Master Thesis, MIT (Research Report to Federal Reserve Bank of Boston, 1965, No. 29).

[19] Philpot, Nigel, "Managing the Export Function", Management Survey Report, No. 26, British Institute of Management, London, T975.

[20] Schaeffer, Sidney, Robert D. Buzze11, and Donald F. Heany, "Impact of. Strategic Planning on Profit Performance", Harvard Business Review, March-April 1974, pp. 137-145.

[21] Simpson, Claude L., Jr. and Duane Kujawa, "The Export Decision Process: An Empirical Inquiry", Journal of International Business Studies, Spring 1974, pp. 107-117.

[22] Sweeney, James K., "A Small Company enters the European Market", Harvard Business Review, Sept.-Oct. 1970, pp. 126-132.

[23] Tookey, D.A., "Factors Associated with Success in Exporting", Journal of Management Studies, March 1964 (1), pp. 48-64.

[24] Wind, Yoram, Susan P. Douglas and Howard V. Perlmutter, "Guidelines for Developing International Marketing Strategies", Journal of Marketing, Apri1 1973, pp. 14-20. 


\author{
Faculty of Business \\ McMaster University \\ WORKING PAPER SERIES
}

101. Torrance, George W., "A Generalized Cost-effectiveness Model for the Evaluation of Health Programs," November, 1970.

102. Isbester, A. Fraser and Sandra C. Castle, "Teachers and Collective Bargaining in Ontario: A Means to What End?" November, 1971.

103. Thomas, Arthur L., "Transfer Prices of the Multinational Firm: When Will They be Arbitrary?" (Reprinted from: Abacus, Vol. 7, No. 1, June, 1971).

104. Szendrovits, Andrew Z., "An Economic Production Quantity Model with Holding Time and Costs of Work-in-process Inventory," March, 1974.

111. Basu, S., "Investment Performance of Common Stocks in Relation to their Price-earnings Ratios: A Text of the Efficient Market Hypothesis," March, 1975.

112. Truscott, William G., "Some Dynamic Extensions of a Discrete LocationAllocation Problem," March, 1976.

113. Basu, S. and J.R. Hanna, "Accounting for Changes in the General Purchasing Power of Money: The Impact on Financial Statements of Canadian Corporations for the Period 1967-74," April 1976. (Reprinted from Cost and Management, January-February, 1976).

114. Deal, K.R., "Verification of the Theoretical Consistency of a Differential Game in Advertising," March, 1976.

114a. Deal, K.R., "Optimizing Advertising Expenditures in a Dynamic Duopoly," March, 1976.

115. Adams, Roy J., "The Canada-United States Labour Link Under Stress," [1976].

116. Thomas, Arthur L., "The Extended Approach to Joint-Cost Allocation: Relaxation of Simplifying Assumptions," June, 1976.

117. Adams, Roy J. and C.H. Rummel, "Worker's Participation in Management in West Germany: Impact on the Work, the Enterprise and the Trade Unions," September, 1976.

118. Szendrovits, Andrew Z., "A Comment on 'Optimal and System Myopic Policies for Multi-echelon Production/Inventory Assembly Systems'," [1976].

119. Meadows, Ian S.G., "Organic Structure and Innovation in Small Work Groups," October, 1976. 
120. Basu, S., "The Effect of Earnings Yield on Assessments of the Association Between Annual Accounting Income Numbers and Security Prices," October, 1976.

121. Agarwal, Naresh C., "Labour Supply Behaviour of Married Women - A Model with Permanent and Transitory Variables," October, 1976.

122. Meadows, Ian S.G., "Organic Structure, Satisfaction and Personality," October, 1976.

123. Banting, Peter M., "Customer Service in Industrial Marketing: A Comparative Study," October, 1976. (Reprinted from: European Journal of Marketing, Vol. 10, No. 3, Summer, 1976).

124. Aivazian, V., "On the Comparative-Statics of Asset Demand," August, 1976.

125. Aivazian, V., "Contamination by Risk Reconsidered," October, 1976.

126. Szendrovits, Andrew Z. and George 0. Wesolowsky, "Variation in Optimizing Serial Multi-State Production/Inventory Systems, March, 1977.

127. Agarwal, Naresh C., "Size-Structure Relationship: A Further Elaboration," March, 1977.

128. Jain, Harish C., "Minority Workers, the Structure of Labour Markets and Anti-Discrimination Legislation," March, 1977.

129. Adams, Roy J., "Employer Solidarity," March, 1977.

130. Gould, Lawrence I. and Stanley N. Laiken, "The Effect of Income Taxation and Investment Priorities: The RRSP," March, 1977.

131. Callen, Jeffrey L., "Financial Cost Allocations: A Game-Theoretic Approach," March, 1977.

132. Jain, Harish C., "Race and Sex Discrimination Legislation in North America and Britain: Some Lessons for Canada," May, 1977.

133. Hayashi, Kichiro. "Corporate Planning Practices in Japanese Multinationals." Accepted for publication in the Academy of Management Journal in 1978.

1-34. Jain, Harish C., Neil Hood and Steve Young, "Cross-Cultural Aspects of Personnel Policies in Multi-Nationals: A Case Study of Chrysler UK", June, 1977.

135. Aivazian, V. and J.L. Callen, "Investment, Market Structure and the Cost of Capital", July, 1977. 
136. Adams, R.J., "Canadian Industrial Relations and the German Example", October, 1977.

137. Callen, J.L., "Production, Efficiency and Welfare in the U.S. Natural Gas Transmission Industry", October, 1977.

138. Richardson, A.W. and Wesolowsky, G.0., "Cost-Volume-Profit Analysis and the Value of Information", November, 1977.

139. Jain, Harish C., "Labour Market Problems of Native People in Ontario", December, 1977.

140. Gordon, M.J. and L.I. Gould, "The Cost of Equity Capital: A Reconsideration", January, 1978.

141. Gordon, M.J. and L.I. Gould, "The Cost of Equity Capital with Personal Income Taxes and Flotation Costs", January, 1978.

142. Adams, R.J., "Dunlop After Two Decades: Systems Theory as a Framework For Organizing the Field of Industrial Relations", January, 1978.

143. Agarwa1, N.C. and Jain, H.C., "Pay Discrimination Against Women in Canada: Issues and Policies", February, 1978.

144. Jain, H.C. and Sloane, P.J., "Race, Sex and Minority Group Discrimination Legislation in North America and Britain", March, 1978.

145. Agarwal, N.C., "A Labour Market Analysis of Executive Earnings", June, 1978.

146. Jain, H.C. and Young, A., "Racial Discrimination in the U.K. Labour Market: Theory and Evidence", June, 1978.

147. Yagil, J., "On Alternative Methods of Treating Risk," September, 1978.

148. Jain, H.C., "Attitudes toward Communication System: A Comparison of Anglophone and Francophone Hospital Employees," September, 1978.

149. Ross, R., "Marketing Through the Japanese Distribution System", November, 1978.

150. Gould, Lawrence I. and Stanley N. Laiken, "Dividends vs. Capital Gains Under Share Redemptions," December, 1978.

151. Gould, Lawrence I, and Stanley N. Laiken, "The Impact of General Averaging on Income Realization Decisions: A Caveat on Tax Deferral," December, 1978.

152. Jain, Harish C., Jacques Normand and Rabindra N. Kanungo, "Job Motivation of Canadian Anglophone and Francophone Hospital Employees, April, 1979.

153. Stidsen, Bent, "Communications Relations", April, 1979.

154. Szendrovits, A.Z. and Drezner, Zvi, "Optimizing N-Stage Production/ Inventory Systems by Transporting Different Numbers of Equal-Sized Batches at Various Stages", April, 1979. 
155. Truscott, W.G., "Allocation Analysis of a Dynamic Distribution Problem", June, 1979.

156. Hanna, J.R., "Measuring Capital and Income", November, 1979.

157. Deal, K.R., "Numerical Solution and Multiple Scenario Investigation of Linear Quadratic Differential Games", November, 1979.

158. Hanna, J.R., "Professional Accounting Education in Canada: Problems and Prospects", November, 1979.

159. Adams, R.J., "Towards a More Competent Labor Force: A Training Levy Scheme for Canada", December, 1979.

160. Jain, H.C., "Management of Human Res.ources and Productivity", February, 1980 .

161. Wensley, A., "The Efficiency of Canadian Foreign Exchange Markets", February, 1980.

162. Tihanyi, E., "The Market Valuation of Deferred Taxes", March, 1980.

163. Meadows, I.S., "Quality of Working Life: Progress, Problems and Prospects", March, 1980.

164. Szendrovits, A.Z., "The Effect of Numbers of Stages on Multi-Stage Production/Inventory Models - An Empirical Study", April, 1980.

165. Laiken, S.N., "Current Action to Lower Future Taxes: General Averaging and Anticipated Income Models", April, 1980.

166. Love, R.F., "Hull Properties in Location Problems", April, 1980.

167. Jain, H.C., "Disadvantaged Groups on the Labour Market", May, 1980.

168. Adams, R.J., "Training in Canadian Industry: Research Theory and Policy Implications", June, 1980.

169. Joyner, R.C., "Application of Process Theories to Teaching Unstructured Managerial Decision Making", August, 1980.

170. Love, R.F., "A Stopping Rule for Facilities Location Algorithms", September, 1980 .

171. Abad, Prakash L., "An Optimal Control Approach to Marketing - Production Planning", October, 1980.

172. Abad, Prakash L., "Decentralized Planning With An Interdependent Marketing-Production System", October, 1980.

173. Adams, R.J., "Industrial Relations Systems in Europe and North America", October, 1980. 
174. Gaa, James C., "The Role of Central Rulemaking In Corporate Financial Reporting", February, 1981.

175. Adams, Roy J., "A Theory of Employer Attitudes and Behaviour Towards Trade Unions In Western Europe and North America", February, 1981.

176. Love, Robert F. and Jsun Y. Wong, "A 0-1 Linear Program To Minimize Interaction Cost In Scheduling", May, 1981.

177. Jain, Harish, "Employment and Pay Discrimination in Canada: Theories, Evidence and Policies", June, 1981.

178. Basu, S., "Market Reaction to Accounting Policy Deliberation: The Inflation Accounting Case Revisited", June, 1981.

179. Basu, S., "Risk Information and Financial Lease Disclosures: Some Empirical Evidence", June, 1981.

180. Basu, S., "The Relationship between Earnings' Yield, Market Value and Return for NYSE Common Stocks: Further Evidence", September, 1981

181. Jain, H.C., "Race and Sex Discrimination in Employment in Canada: Theories, evidence and policies", July 1981.

182. Jain, H.C., "Cross Cultural Management of Human Resources and the Multinational Corporations", October 1981.

183. Meadows, Ian, "Work System Characteristics and Employee Responses: An Exploratory Study", October, 1981.

184. Svi Drezner, Szendrovits, Andrew Z., Wesolowsky, George 0. "Multi-stage Production with Variable Lot Sizes and Transportation of Partial Lots", January, 1982.

185. Basu, S., "Residual Risk, Firm Size and Returns for NYSE Common Stocks: Some Empirical Evidence", February, 1982.

186. Jain, Harish C. and Muthuchidambram, S. "The Ontario Human Rights Code: An Analysis of the Public Policy Through Selected Cases of Discrimination In Employment", March, 1982.

18.7. Love Robert F., Dowling, Paul D., "Optimal Weighted \& Norm Parameters For Facilities Layout Distance Characterizations", PApril, 1982.

188. Steiner, G., "Single Machine Scheduling with Precedence Constraints of Dimension 2", June, 1982.

189. Torrance, G.W. "Application of Multi-Attribute Utility Theory To Measure Social Preferences For Health States", June, 1982. 
190. Adams, Roy J., "Competing Paradigms in Industrial Relations", April, 1982.

191. Callen, J.L., Kwan, C.C.Y., and Yip, P.C.Y., "Efficiency of Foreign Exchange Markets: An Empirical Study Using Maximum Entropy Spectral Analysis." July, 1982.

192. Kwan; C.C.Y., "Portfolio Analysis Using Single Index, Multi-Index, and Constant Correlation Models: A Unified Treatment." July, 1982

193. Rose, Joseph B., "The Building Trades - Canadian Labour Congress -Dispute", September, 1982

194. Gould, Lawrence I., and Laiken, Stanley N., "Investment Considerations in a Depreciation-Based Tax Shelter: A Comparative Approach". November 1982.

195. Gould, Lawrence I., and Laiken, Stanley N., "An Analysis of Multi-Period After-Tax Rates of Return on Investment". November 1982 .

196. Gould, Lawrence I., and Laiken, Stanley -N., "Effects of the Investment Income Deduction on the Comparison of Investment Returns". November 1982.

197.

G. John Miltenburg, "Allocating a Replenishment Order Among a Family of Items", January 1983. 
Innis HB

74.5

. R4

no. 19 